\title{
The higher education in modern russia as institute of cultural transfer and transformation
}

\author{
Narkhova, Elena N. ${ }^{\text {; }}$ Narkhov, Dmitry Yu. ${ }^{\text {; }}$ Kalyuzhnaya, Ekaterina G. ${ }^{\text {c }}$ \\ a Department of the theory, methodology and legal support of the public and municipal \\ administration Ural Federal University named after B.N. Yeltsin, Ekaterinburg, Russia, b \\ Department of Organizing Youth Work, Ural Federal University named after B.N. Yeltsin, \\ Ekaterinburg, Russia, ${ }^{\mathrm{c}}$ Department of management in the sphere of physical culture and \\ sport, Ural Federal University named after B.N. Yeltsin, Ekaterinburg, Russia
}

\begin{abstract}
The problem of changes in modern Russian education is analyzed in the article. Modernization of the Russian education system staticized questions of a ratio of traditions and innovations in education, about maintaining parity of training and education. The article's purpose is to define the mechanism for implementation of upbringing in the system of modern Russian education as culrure traditions (2014-2017).

The research of the relation of workers from science and pedagogical sphere, students, administrative personnel and management to this issue influences on their activity effectiveness. Extent of consent with different points of view actualizes the potential of communities of education that appears in the form of the social capital.

Authors emphasize the value of an educative role of education institute as a culture translator because people get their own perception of the world, of the appraisal systemthe system of coordinates, including values in the course of education and comprehension of the world. The cultural background that the person perceives in the process of education, gives the chance to perceive both modern reality and him or herself in this reality more multilaterally.
\end{abstract}

Keywords: higher education; traditions; social institutes; cultural polistilizm; modernization of education, upbringing of students 


\section{Introduction}

One of the main cultural institutes is education. Its model defines the direction of society development in general and formation of the personality certain type. The civilizational mission of education is the transfer of sociocultural experience to new generations. The system of the higher education is an important social institute of cultural values broadcast as a part of professional education, professional formation and development of the personality.

The processes that could be seen at the modern Russian higher school as multidimensional and ambiguous phenomena can be described and defined within the social transformations happening in modern Russian society. These transformations are inseparably linked with revaluation of the ideas and search of the new semantic reference points that may give Russian society stability that is in a condition of an anomy. The kernel of values of the Soviet culture is destroyed, and new one is still developing, there is a search of various valuable models and options. The culture of modern Russian society is contradictory, ambivalent, "polistylistic" (term by L.G. Ionin, 1996) that is caused by the nature of modern culture which is opened, has a set of valuable systems, interaction and mutual enrichment of national cultures. Other aspect of modern culture - commitment to the idea of a deconstruction of traditional norms, samples, the values developed by mankind during history (Kurennay V. A., 2011). During an era of mass culture and devaluation of moral values the higher education loses the elitism, the personal forming and socializing functions, turning into ordinary educational service (Ogurtsov A. P., 2001).

However the higher school as an institute and the mechanism of cultural reproduction in society is urged to support creative tendencies and to resist destructive calls of the present. The combination of various cultural models is the cornerstone of historical development experience of the higher school (Karrye G., 1996). Values, content of preparation, mechanisms and the corresponding standards of creation of educational process have always been caused by the ideology dominating in society and the cultural dominant generated by it (Shutenko A. I. 2013). So, in the Soviet society the ideology has subordinated the higher school to political goals and tasks. Based on the concept of a power culture dominance, the higher school first of all had to form such values as "devotion" and "fidelity" to the ruling party or to the individual person.

What can provide stability of an educational process creation in the Russian higher school today in the era of uncertainty?

In the conditions of searching the Russian society education development vector the question of correlation between functions of upbringing and education in educational process is debatable. Some authors (traditionalists) prove the need of preservation of both functions for their close interrelation that corresponds to traditions of Russian education 
(Yemelyanova I.N. ect., 2012; Medvedeva O. Yu., 2002; Vidt. I. E., 2006). Innovators, who support modernization changes, allocate cultural functions in the list of the universities' social functions, insist on "gradual rapprochement of the training and bringing up activity in the form of integration ..." (Vidt. I. E., 2006, p. 179), but leave a question of a correlation between upbringing and education opened (The Role of Universities, 2010). Foreign researchers criticize the federal universities for obvious focus on social responsibility which disturbs competitiveness at the global level (Jonson, M., 2010, p. 19).

The discussion is conducted not only in Russian but also in the whole world educational space. In particular, there was a speech in the deployed keynote of professor Piet Kommers at the last HEAd conference '17 (Kommers, P., 2017) about a role of "the understanding education", based on L.S. Vygotsky philosophical views. The understanding is connected with familiarizing with meanings of human activity and with process of a sence retreatment and determined by the spiritual potential of the subject, its system of worldview values and socio-cultural prerequisites of reality understanding.

The type of the personality that is motivated on self-change, self-development and capable to create socially significant products of own professional activity is demanded in the modern world. In this case, the personality becomes the education purpose, and education as institute of culture becomes a factor of the personality development. The priority of the personality forms an axis of educational process building at the higher school and establishes a dominant of culture. It defines opportunities for educational practices aimed at the personality development in the unity of its consciousness (valuable orientations) and activities.

\section{The studied structures, processes, phenomena and methods}

The research is intended to reveal the changes in functioning of higher education institute caused by the societal consequences of transformations of the Post-Soviet period and the followed multivector modernization of the higher education. Considerable changes are implemented in the structural, institutional and substantial directions. The greatest discussions both in scientific community and among public servants in the last decades cause the problems connected with educational activity of higher education institutions. We were interested in the relation towards the process of educational activity of scientific and pedagogical workers and students.

Results of the next researches are the basis for work.

1) Federal complex sociological poll of teachers of higher education institutions (20132014), $N=1115$, quota representative selection, the basis for quoting - the status of higher education institution acquired as a result of structural modernization (national, federal, 
national research, other) 51 state and private higher education institution from 32 cities of Russia.

2) The federal sociological poll of students devoted to problems of justice and inequality in modern society, a method of casual selection, $\mathrm{N}=3964$, 71 higher education institution from all regions of Russia;

3) Regional complex sociological poll of students of Sverdlovsk region (2016), $\mathrm{N}=2170$, two-step quota representative sampling, the basis for quoting - the number of students, the place of a location of higher education institution and specialty.

4) Content analysis of personal pages of students and research and teaching staff of the universities, 2016-2017, N=230, social network VKontakte (vk.com).

\section{Discussions and results}

Formation and development of the personality continues in the conditions of learning in higher education institution. Training of the younger generation to professional activity at the higher school can't be limited to gaining a certain sum of knowledge. Except gaining knowledge and professional skills, future expert need to orientate on moral and ethical standards that is significant in the conditions of values and standards system blurring of modern society. However, at the state level an indicator "educational work" isn't considered at higher educational institutions accreditation in the Russian education system. It doesn't promote the solution of an important task - upbringing the identity of the expert. According to teachers, modernization changes in universities haven't led to any increase of a role of the teacher in educational activity (which we consider as the most important element of education tradition). Every second teacher is the participant of federal survey in 2014 told about it (and every fourth one hasn't chosen the answer). Nevertheless, the missionary mentality of university staff has remained. As a result, the cultural potential of scientific and pedagogical workers is implemented mainly in classrooms (table 1). 
Narkhova, E. N., Narkhov, D. Yu., Kalyuzhnaya, E. G.

Table 1. Extent of participation of teachers in educational work with students, 2014, \% of number of answered

\begin{tabular}{|c|c|c|c|c|c|c|}
\hline \multirow[t]{2}{*}{ Ways of participation } & \multicolumn{3}{|c|}{ Do not participate } & \multicolumn{3}{|c|}{ Participate actively } \\
\hline & 1 & 2 & 3 & 4 & 5 & Index* \\
\hline $\begin{array}{l}\text { I form an active civic stand by all available } \\
\text { means }\end{array}$ & 9 & 14 & 22 & 22 & 33 & 0,57 \\
\hline $\begin{array}{l}\text { I am engaged in educational activity only on } \\
\text { occupations }\end{array}$ & 9 & 9 & 26 & 27 & 29 & 0,58 \\
\hline $\begin{array}{l}\text { I participate in the events held within } \\
\text { educational activity together with students, at } \\
\text { faculty, in higher education institution }\end{array}$ & 24 & 14 & 20 & 16 & 27 & 0,08 \\
\hline $\begin{array}{l}\text { I participate in organization of events within } \\
\text { educational activity of faculty, higher } \\
\text { education institution }\end{array}$ & 29 & 13 & 18 & 19 & 22 & $-0,08$ \\
\hline $\begin{array}{l}\text { I am engaged in educational activity as the } \\
\text { curator of the academic group }\end{array}$ & 57 & 4 & 9 & 14 & 16 & $-0,72$ \\
\hline $\begin{array}{l}\text { I participate in the events held within } \\
\text { educational activity together with students, in } \\
\text { the city, the territorial subject of the Russian } \\
\text { Federation }\end{array}$ & 48 & 16 & 15 & 11 & 11 & $-0,77$ \\
\hline $\begin{array}{l}\text { I participate in the events held within } \\
\text { educational activity together with students, in } \\
\text { the all-Russian and international actions }\end{array}$ & 57 & 14 & 12 & 10 & 8 & $-1,00$ \\
\hline $\begin{array}{l}\text { I participate in organization of events within } \\
\text { educational activity in the city, the territorial } \\
\text { subject of the Russian Federation }\end{array}$ & 58 & 13 & 12 & 9 & 8 & $-1,04$ \\
\hline $\begin{array}{l}\text { I participate in the organization of the all- } \\
\text { Russian, international actions within } \\
\text { educational activity }\end{array}$ & 67 & 10 & 9 & 7 & 7 & $-1,22$ \\
\hline $\begin{array}{l}\text { I direct educational processes and youth } \\
\text { policy at the level of the city, the territorial } \\
\text { subject of the Russian Federation }\end{array}$ & 72 & 8 & 5 & 7 & 8 & $-1,29$ \\
\hline $\begin{array}{l}\text { I direct educational processes and youth } \\
\text { policy at the all-Russian, international level }\end{array}$ & 85 & 8 & 3 & 1 & 4 & $-1,69$ \\
\hline $\begin{array}{l}\text { I direct educational processes and youth } \\
\text { policy at the level of faculty, higher education } \\
\text { institution }\end{array}$ & 88 & 6 & 3 & 2 & 2 & $-1,75$ \\
\hline
\end{tabular}

The numerous problems of the younger generation are the result of the lack of attention to purposeful educational work at the higher school that is caused by lack of accurate system of values which may appear due to the only way - through education. At the regional level it was shown in structure fluctuations of Sverdlovsk region students' valuable orientations: 
high degree of hedonism (Vishnevsky Yu.R. ect., 2017, STUDENT..., pp. 395-407), education shift from the category of terminal values in tool [Vishnevsky Yu.R. ect., 2017, STUDENT..., p.421], slowly decreasing share believing that it is optional to observe laws (in 2007 - 77\%, in 2016 - 64\% had justifications to break the law, most often because the law limits the rights of the personality) [Vishnevsky Yu.R. ect., 2017, STUDENT..., p. 505]. At the all-Russian level the cultural anomy and broad dispersion of students has proved in estimates of the Russian society as rather unfair, than fair $(3,78 \pm 0,13$ on a 10 mark scale). Such assessment reflects ambiguous socio-economic and socio-political installations created by education with discrepancy in valuable orientations: on the one hand, installations on own forces, enterprise abilities and creativity, so far as concerns own wellbeing, and on the other hand, installations on paternalism, guardianship from parents and the state, so far as concerns wellbeing of surrounding social space (Vishnevsky Yu. R. \& Narkhov D. Yu., 2017, p. 36-37).

At last, the analysis of personal pages of students on social networks confirms a conclusion about dispersion of valuable orientations. Along with an interiorization of examples of high academic culture, an avatar of students also shows a considerable participation in countercultural processes, such as trolling, deviant subcultural samples, etc.

Meanwhile, one of the modernization theory representative R. Inglkhart claims that transition to post-industrial society brings cultural wealth to the forefront again. The understanding of the purpose and sense of human existence is again regarded as the issue of paramount importance. At the same time he notes: "expansion of not materialistic values happens very quickly that this phenomenon is connected with alternation of generations and caused by gradual change of motivation, increase in material well-being and growth of educational level of people. Considering that development of post-materialistic values causes economic and cultural progress of the western countries in recent years, it is possible to seriously doubt in reality of the entry of Russia into a number of post-industrial powers, to get rid of the illusions existing in this respect" (Inglehart F. P., 1990, p. 247).

\section{Conclusion}

Now educational work at the higher Russian school isn't a priority as the higher school is considered as the level of professional education that assumes formation of professional qualities, and the educational component is considered in the context of the training strategy formation. Personal qualities aren't programmed by standards of the higher education as they enter common cultural mix and inherit the tradition which has come from the fundamental education where upbringing work is one of the important vectors of the personality development.

Education values for the teacher of higher education institution need to be considered at three levels: education in the course of training, education at the level of realization of the 
practice module and in the course of out-of-class activity. Teachers, as a rule, aren't engaged in out-of-class activity, therefore the educational component is shown in the context of teaching and work with students on practicians.

On the one hand, in a pursuit of professionalism, based on competence-based approach, authors of the program of modernization of the Russian higher education "have lost sight" of the cultural expert for some time, having placed emphasis on especially professional, technological competences of educational process to the detriment of common cultural competences. The latter remains the declaration of working programs of disciplines, but not educational practice. We believe that maintaining traditional balance between training and education in Russian education, the active and positive social position of the university teacher is defined by prospects of the higher education. In this regard as a practical measure it is correct to return educational activity to number of accreditation indicators of the universities. In wider plan if the true professional (but not the robot performer) is needed, it is worth paying attention to experience of modernization of education, based on maintaining traditions in education (see: He Chuanqi, 2011).

On the other hand, it is difficult to divide the training and educational functions of higher education institute. Process of students upbringing carries out as well an educational function (especially in the sphere of humanitarian knowledge) when through the culture of the past comprehension and own valuable orientations formation the person also acquires the system of internal reference points when the peculiar interiorization of culture of the past happens (for example, in the context of culture of the past experience reflection the person can analyze processes of modern sociocultural reality). The cultural background which the person perceives in the course of education gives the chance to more multilaterally perceive the modern reality and him or herself in this reality. Educational work in universities shouldn't be considered as something isolated - as soon as a complex separate from lectures and seminars of educational actions. For example, within teaching disciplines of a humanitarian cycle, students ability development to more difficult understanding of the world and themselves is already supposed. The task of higher education, at least of its humanitarian part, is "to make" people more complicated, to teach them not unilinear but volume view of the world and perceptions of diverse reality. Such task can be quite incorporated in a framework of training process at the higher school and the cultural values transfer can be carried out through the transfer of the culture itself and cultural samples of the past and the present in their interaction, through the story about how the image of the world during different cultural eras changed as cultural samples were transformed. The solution of this task contributes to the development of students' ability to correlate different valuable paradigms, views of the world for formation of understanding of complexity of the world and awareness of impossibility to cross all-humanistic sides of human life. 
It is important to acquaint students with problems and calls of the present and with certain transitional situations in modern culture when there is a need to form new meanings and values instead of the unstable ones. Partly remaining, values of traditional culture have to be complemented with some new meanings. The 20th century has generated a situation of loss of immutable belief in some traditional values, the syncretism of perception of a picture of the world declared by a certain ideology has disappeared. But whether it means a loss of meaning? If this is so, then the anomy becomes norm. The goal of culture in new conditions is to help to find new personal meanings, to find somewhere a support in former meanings, to formulate new ones.

Modernization processes in the Russian system of the higher education have to be aimed especially at providing of the education and students qualities upbringing in the framework of their professional training and the inclusion of an upbringing component in the educational process.

\section{References}

He Chuanqi (2011). Summary report on the modernization in the world and in China (2001-2010) Translated from English. Under the editorship of N.I. Lapin. Moscow: Publishing house “Ves Mir”. (In Russ.).

Inglehart F. P. (1990) Culture Shift in Advanced Industrial Society, Princeton University Press.

Ionin L. G. (1996) Culture of Sociology. Moscow: Lagos. (In Russ.).

Jonson, M. (2010). Rediscovery of Public Research Universities in $21^{\text {th }}$ century: The Balance of Global Competition, Regional Partnership and Community Engagement. In: The Role of Universities in the development of region: papers for Consideration (2010). International Conference, January 28-29, 2010; Ekaterinburg, USU, CASE \& Civil Chamber of the Russian Federation, pp. 16-21. (In Russ. and Eng).

Karrye G. (1996). Cultural models of the university. Alma mater, 3, 15 - 24. (In Russ.)

Kommers, Piet. (2017). Learning for Societal Evolution (Keynote). $3^{\text {nd }}$ International Conference on Higher Educational Advances, June 21-23, Valencia, Span.

Kruzhalin V.I. (ed.) (2010). Quality of university education: state, problems, prospects: scientific works of Institute of complex researches of formation of Lomonosov Moscow State University. Moscow, Dialogue of cultures, 68-79. (In Russ.).

Kurennay V. A. (2011). Bastard of a modernist style. About the current crisis of the university. The Emergency ration, 3 (77), 103-110.

Medvedeva O. Yu. (2002) Cultural tradition in education. Outlook and culture: collection of articles. Under a general edition of the prof. V.V. Kim; The Russian philosophical 
society, etc. - Ekaterinburg: Bank of Cultural Information publishing house, 303-309. (In Russ.).

Ogurtsov A. P. (2001). Postmodern image of the person and pedagogics. Person, 3, 5-17. (In Russ.).

Shutenko A. I. (2013). Sociocultural measurements of steady pedagogical process at the higher school. Knowledge. Understanding. Ability, 4, 249-251. (In Russ.).

The Role of Universities in the development of region: papers for Consideration (2010). International Conference, January 28-29, 2010; Ekaterinburg, USU, CASE \& Civil Chamber of the Russian Federation, 144 p. (In Russ. and Eng).

Vidt. I. E. (2006). Education as culture phenomenon. Tyumen: Printer publishing house.

Vishnevsky Yu.R. (gen. ed.), Bannikova L. N. [etc.] (2017). STUDENT of 1995-2016: dynamics of sociocultural development of students of Central Ural Mountains, Ekaterinburg: Yeltsin UrFU. (In Russ.).

Vishnevsky Yu. R. \& Narkhov D. Yu. (2017) What society is just: views of Sverdlovsk region students. Sociological studies. 5, 35-46.

Yemelyanova I. N. (gen. ed.) ect. (2012). Formation of the spiritual and moral environment of educational institution. Tyumen: Publishing house of the Tyumen state university (2012). 